\title{
Truncation in the Spanish left-periphery: fragment answers and recomplementation
}

\author{
Carlos de Cuba \& Jonathan E. MacDonald*
}

LSA Annual Meeting, Minneapolis, January 2-5, 2014

1. Introduction. In this paper, we discuss the contrast between two classes of predicates: those that can embed fragment answers and those that cannot. We show that these predicate classes differ not only in the general the availability of fragment answers but also in the availability of the complementizer que in certain constructions as well as the availability of the phenomenon known as recomplementation, as discussed by Villa-García (2012) and Demonte \& FernándezSoriano (2009) among others. We propose that the syntactic differences between the two classes of predicates arise because these predicates select different types of clausal complements. Specifically, we claim that the complements to predicates that do not allow fragment answers or recomplementation have a truncated left periphery. The lack of structural positions in these complements rules out fragment answers and recomplementation. For expository purposes we illustrate how these phenomena might be handled under a cartographic approach (Rizzi 1997), where a truncated left periphery lacks the projections ForceP and TopP. However, this does entail that a derivational approach could not handle these facts in a similar way. Nevertheless, space constraints prevent us from illustrating a full contrastive cartographic vs. non-cartographic approach to these phenomena.

2. Data patterns. In this section we present the relevant observations on embedding in Spanish.

FIRST OBSERVATION. In response to a $w h$-question like (1), some predicates can embed fragment answers, as in (2a), and some cannot, as in (2b).

¿Quién robó las joyas?

Who stole the jewels?

(2) a. Me dijeron/pienso que tu hijo.

Me they.said/I.think that your son

"They told me/I think that your son (did it)."

b. *Lamento/se que tu hijo.

I.regret/I.know that your son

"I regret/I know that your son (did it)."

Fragment answer embedding predicates include those given in (3) and non-fragment answer embedding predicates include those given in (4). Traditionally the predicates in (3) have been called non-factive and those in (4) factive. However, we follow current work (de Cuba \& Ürögdi 2009, Haegeman \& Ürögdi 2010, de Cuba \& MacDonald 2013) in classifying the "typical" clausal complements of the predicates in (3) as non-referential and the "typical" clausal complements of the predicates in (4) as referential ("typical" to be discussed below).

\footnotetext{
* We thank audiences at LSRL 2013 (CUNY), CGG 2013 (Universidad Complutense de Madrid), The University of Calgary, The University of Illinois Urbana-Champaign and The University of Iowa, where previous versions of this paper were presented. All errors, of course, are our own. Authors: Carlos de Cuba, University of Calgary (lin200cdc@ hotmail.com) \& Jonathan E. MacDonald, University of Illinois at Urbana-Champaign (jonmacd@illinois.edu).
} 
(3) Non-referential clausal complement taking predicates: decir "say", pensar "think", creer "believe", suponer "suppose", imaginarse "imagine", sospechar "suspect", among others.

(4) Referential clausal complement taking predicates: lamentar "regret", saber "know", odiar "hate", sentirlo "be sorry", explicar "explain", desagradar "displease" among others.

SECOND OBSERVATION. When one of the predicates in (3) embeds a fragment answer, the complementizer que must be present, as shown in (6).

(5) ¿Quién robó las joyas?

Who stole the jewels?

(6) a. Me dijeron*(que) tu hijo.

me told *(that) your son

"They told me your son (did)."

b. Pienso *(que) tu hijo.

think *(that) your son

"I think your son (did)."

THIRD OBSERVATION. Some predicates allow recomplementation, which is syntactically characterized by Villa-Garcia (2012) as a left-dislocated constituent sandwiched between two occurrences of que, as in (7).

(7) Susi dice que a los alumnos (que) les van a dar regalos.

Susi say that to the students (that) them go to give gifts

"Susi says that they will give gifts to the students." (Villa-Garcia 2012:258)

Also note in (7) that predicates like decir "say" that allow recomplementation also allow embedded fragment answers. (8) shows that the predicates in (4), which do not allow fragment answers, also do not allow recomplementation.

(8) Lamento que ese coche (*que) no lo compres.

regret that that car that not it buy

"I am sorry that you won’t but that car." (Demonte \& Fernández-Soriano 2009:47)

FOURTH OBSERVATION. With recomplementation, $w h$-words can only appear under the rightmost que, as illustrated in (9).

(9) a. Me preguntó que mi madre que cuándo podría venir.

me ask that my mother that when could come

"S/he asked when my mother could come."

b. *Me preguntó que cuándo que mi madre podría venir.

me ask that when that my mother could come

"S/he asked when my mother could come." (Villa-Garcia 2012:267)

This is reminiscent of Suñer's (1991) indirect questions, where some predicates can embed a sequence of que $+w h$-word, as in (10a) and some cannot, as in (10b).

(10) a. Dije que a quién habían detenido.

said that to whom had arrested

"I asked who they had arrested." (Suñer 1991:289) 
b. Juana no sabía (*que) cuándo visitaría sus abuelos.

Juana not know that when visit her grandparents

Juana didn't know when her grandparents would visit.” (Suñer 1991:284)

\section{SUMMARY OF OBSERVATIONS}

- The set of predicates in (3) allows embedded fragment answers (requiring que), recomplementation and the sequence que $+w h$-word in the complement.

- The set of predicates in (4) does not allow embedded fragment answers, recomplementation or the sequence que $+w h$-word in the complement.

In the next section we offer a unified analysis to account for these patterns within a cartographic approach to the left-periphery.

3. Proposal. In the spirit of de Cuba \& Ürögdi 2009 and de Cuba \& MacDonald 2013, we claim that there are two types of clausal complements, non-referential and referential, and that nonreferential complements are structurally more complex than referential complements. We propose the structures in (11), where non-referential complements consist of Force, TopP, FocP, and FinP, and referential of only FocP and FinP.

(11) a. Non-referential complement: embedded fragment answers, recomplementation, que $+w h$-word

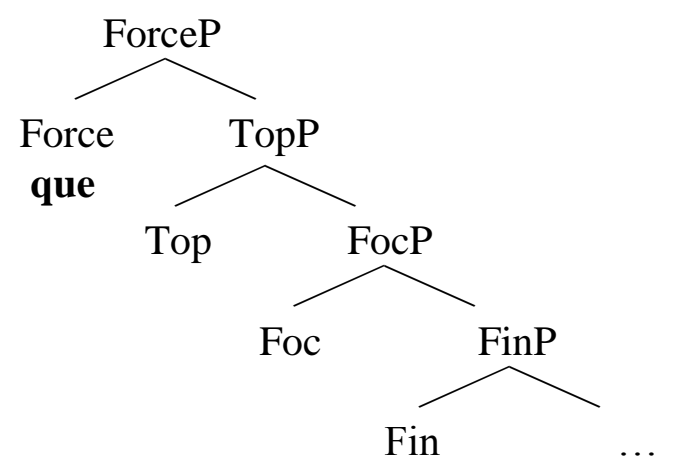

b. Referential complement: no embedded fragment answers, no recomplementation, no que $+w h$-word

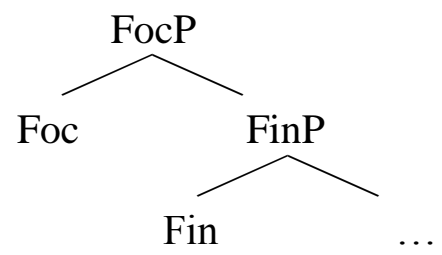

Following de Cuba \& Ürögdi 2009 and de Cuba \& MacDonald 2013, we claim that clausal complement taking predicates typically to take one or the other. The predicates in (3) usually take non-referential complements and the predicates in (4) referential complements. However, some predicates can take either complement, in which case their complements can be either referential or non-referential; thus the use of "tend", "typically" and "usually". We leave aside the details of the selection properties of these predicate for lack of space and simply refer the reader to the discussion in de Cuba \& Ürögdi 2009 and de Cuba \& MacDonald 2013. 
Our proposal accounts for the data in section 2 in the following way. First, we propose that the que in embedded fragment answers (in (2) and (6)), the highest que in recomplementation structures (in (7) and (9a)) and the que in the que $+w h$-word sequence (in (10a)) are the same que. This que heads a Rizzi-style (1997) ForceP, as in (11a). Second, we follow Villa-Garcia (2012), in claiming that the rightmost occurrence of que in recomplementation (in (7) and (9a)) heads TopP, while the left-most occurrence heads ForceP. Having the rightmost que appear in TopP can help explain the following two facts. First, as noted by Escribano (1991), there can be multiple occurrences of the left-dislocated constituent, something typical of topics, as in (12).

(12) Dijo que el dinero, que a Juan, que se lo mandaban por correo. Said que the money, que to Juan que him it sent by mail "S/he said they were sending John the money through the mail." (Villa-García 2012:266)

Second, wh-items can only appear below the right-most que in indirect questions, as shown in (9) above. This follows if we assume the wh-word in (9a) is in FocP. In sum, we claim that the complements to the predicates in (4) lack ForceP and TopP. If the que of embedded fragment answers heads ForceP and the recursive lower que in recomplementation heads TopP, then we correctly predict that these phenomena will be ruled out under the predicates in (4).

A question remains regarding (8). If the complement to predicates like lamentar is truncated, then where in the left-periphery are the left-dislocated ese coche and the grammatical que in (8) located? One possibility is that there is a lower topic position available, as proposed by a number of authors (Zubizarreta 1998, Ordóñez \& Treviño 1999, Jiménez-Fernández \& Miyagawa 2013, among others). For us this position would be below FinP, which is headed by the grammatical que in (8). This possibility follows if, as Bianchi \& Frascarelli (2010) have proposed, topics that appear in factive complements in Spanish and Italian are G(iven)-Topics, which are syntactically lowest in their hierarchy of topics, below C-Topics and A-Topics.

\section{References}

Bianchi, Valentina and Mara Frascarelli. 2010. Is topic a root phenomenon? Iberia: An International Journal of Theoretical Linguistics 2 (1): 43-88.

de Cuba, Carlos and Jonathan MacDonald. 2013. Referentiality in Spanish CPs. In: Information Structure and Agreement. M. Victoria Camacho Taboada, Ángel Jiménez Fernández, Javier Martín González and Mariano Reyes Tejedor (eds.). Linguistik Aktuell Vol. 197: 117-140. John Benjamins.

de Cuba, Carlos and Barbara Ürögdi. 2009. Eliminating factivity from syntax: Sentential complements in Hungarian. In: Approaches to Hungarian: Vol. 11. Marcel Den Dikken and Robert Vago (eds.). John Benjamins. 29-63.

Demonte, Violeta and Olga Fernández-Soriano. 2009. Force and finiteness in the Spanish complementizer system. Probus 21:23-49.

Haegeman, Liliane, and Barbara Ürögdi. 2010. Referential CPs and DPs: An operator movement account. Theoretical linguistics, 36 (2-3), 111-152.

Jiménez-Fernández, Ángel and Shigeru Miyagawa. 2013. A feature-inheritance approach to root phenomena and parametric variation. Ms., University of Seville and MIT.

Ordóñez, Francisco and Esthela Treviño. 1999. Left dislocated subjects and the pro-drop parameter: A case study of Spanish. Lingua 107:39-68.

Rizzi, Luigi. 1997. The Fine Structure of the Left Periphery. In: Elements of Grammar: A Handbook in Generative Syntax. Liliane Haegeman (ed.). Kluwer: Dordrecht. 281-337.

Suñer, Margarita. 1991. Indirect questions and the structure of CP: Some consequences. In: Current Studies in Spanish Linguistics. Hector Campos and Fernando Martinez-Gil (eds.). Georgetown University Press. 283312.

Villa-García, Julio. 2012. Recomplementation and locality of movement in Spanish. Probus 2012: 24(2): $257-314$. Zubizarreta, Maria Luisa. 1998. Prosody, Focus and Word Order. MIT Press. Cambridge, MA. 